\title{
Transnational youth networks: an evolving form of public diplomacy to accelerate the Sustainable Development Goals
}

\author{
Matias Acosta ${ }^{1,2^{*}}$, Zsofia Szlamka ${ }^{3}$, Mohammed A. Mostajo-Radji ${ }^{4,5,6}$ \\ 1 Argentine Accelerator Lab, United Nations Development Programme, 130 Esmeralda St, C1035ABD \\ Ciudad Autónoma de Buenos Aires, Argentina \\ 2 Centre for Science \& Policy, 10 Trumpington St, Cambridge CB2 1QA, University of Cambridge, United \\ Kingdom \\ 3 Institute of Psychiatry, Psychology and Neuroscience, 16 De Crespigny Park SE5 8AF, King's College \\ London, United Kingdom \\ 4 Clubes de Ciencia Bolivia Foundation, Santa Cruz de la Sierra, Bolivia \\ 5 Ministry of Foreign Affairs of the Plurinational State of Bolivia, La Paz, Bolivia \\ 6 The Eli and Edythe Broad Center of Regeneration Medicine and Stem Cell Research, University of \\ California San Francisco, San Francisco, California, 94143, United States
}

\section{* Correspondence:}

Matias Acosta

matias.acosta@undp.org

Keywords: public diplomacy, diplomacy, transnational youth networks, education, sustainable development goals, youth

According to the United Nations (UN), 41\% of the world's population is under the age of 24 (United Nations Population Division). Despite being a considerably large group, the youth has been commonly underrepresented in decision-making in the public and private sectors. To combat this situation, the UN launched the Youth 2030 strategy in 2018 thereby recognizing the need to empower the youth to reach their full potential (Youth 2030: The UN Youth Strategy). In this contribution, we provide a brief description of some of the recent transnational youth networks (TYNs) and their features in order to discuss the role of such networks to empower the youth. We propose here that such networks constitute a novel and powerful form of public diplomacy (PD) because of their experiential educational aspects that they develop in their members. Moreover, these networks also offer a rather unique opportunity of building interpersonal relationships among global prominent individuals thereby influencing the international agenda. We further discuss how such networks can advance substantially the UN Sustainable Development Goals (SDGs) agenda (Sustainable Development Goals).

While the concept of empowerment can be defined in various ways, we use the concept here following the definition of the UN Social Development Network (United Nations Social Development Network). They conceptualize empowerment as "an iterative process with key components including an enabling 
environment that encourages popular participation in decision-making that affects the achievement of goals like poverty eradication, social integration and decent work for all as well as sustainable development". One of the forms of youth empowerment is through TYNs. We define here TYNs as cross-disciplinary professional groups with members from at least five different countries, under the age of 40, and selected based on a competitive process that analyzes professional achievements. Hence, TYNs connect influential individuals under the age of 40, where the term "influential individuals" is used here to indicate that such individuals were selected based on merit and a procedure that evaluates professional achievements. We highlight here though that the criteria of achievements is arbitrary and may differ considerably among TYNs. In most cases, however, the criteria aims to pinpoint influential individuals which is of relevance for this manuscript as it will become apparent in the discussion. Participation of such individuals in TYNs can have a broad variety of motivations and warrants an investigation which is beyond the scope of this article (Gad, 2009).

As this article discusses the relationship between education and PD through networks, we feel the necessity to define important aspects that will be used for further discussion. Firstly, when we refer here to education, we stress that it will be circumscribed to experiential education. This implies that the aspects that yield learning are based on the life experiences of the TYNs members, whether intended or not, and not necessarily within a conventional educational setting (Joplin, 1981).

Secondly, we should define our understanding of PD as there is a lack of a generalized agreement among academics on the definition and stakeholders involved in it (Ayhan, 2019). According to Gregory(Gregory, 2008), PD entails "an instrument used by states, associations of states, and some sub-state agencies and non-state actors to understand cultures, attitudes, and behavior; to build and manage relationships; and to influence thoughts and mobilize actions to advance their interests and values". As such, it encompasses and reflects the role of both state and non-state actors, namely civil society, to participate in PD activities. In this work, we consider PD scope aligned with the view of non-traditional perspectives (Gilboa, 2008; Nye Jr, 2008). This implies that nonstate actors are capable of engaging in PD initiatives whether they intend or not to take part on it (Ayhan, 2019; Carosso et al., 2019b).

Thirdly, we should introduce two concepts of networks which are of particular relevance here. On the one hand, it has been recognized that organized nonstate actors in, for instance, transnational networks can maximize their influence on PD activities (Haas, 1992; Keck and Sikkink, 2014). This is because they serve as a means to coordinate and align the ideas and values of members (Castells, 2008). There are different network topologies, however, and their topology is also time-dependent (Sekara et al., 2016). The relationship between network topologies and their influence to PD is beyond the scope of this article. Nonetheless, we would like to highlight one particular topology that will be of relevance for further discussion. Manzini(Manzini, 2010) proposed the concept of small, local, open, and connected networks (SLOC) for social innovation systems. In his work, Manzini conceptualized that the most effective approach for systemic change is a mesh of connected local networks owing to the more comprehensible and controllable structure for individuals and local communities. A SLOC network relies greatly on connecting like-minded people and having collective actions and/or goals.

Following these introductory remarks, we provide in Table 1 a non-exhaustive list of some of the most relevant TYNs together with their main features. The selection of these TYN was made based on using different search engines and keywords such as "youth", "young", "network", "leadership", and "global". 
The examples shown are also limited to the definition of TYN provided here and also to a refinement based on the experience of the authors. By analyzing Table 1, it becomes clear that the overarching goal of the TYNs introduced here are to educate and empower their members. Specifically, most recent TYNs also focus particularly on advancing the UN SDGs agenda (see Table 1 and Ref (Gad, 2009)). While in principle the SDGs seem highly interconnected, weighted network linkage analysis showed that there is a great asymmetry between SDGs 1-3 and the remaining goals (Dawes, 2020). Under this model, concentrating global efforts in SDGs 4-16 strongly impact SDGs 1-3, although there is little correlation in the opposite direction. This implies, for example, that concentrating efforts in education through TYNs will, as an effect, reduce poverty and hunger.

Table 1 shows that the governing structures of TYNs varied over time. Those that were born between the 60s and 90s feature more centralized governing structures. An exception to this though is Restless Development, which recently changed its hierarchical structure to a more decentralized version. Networks that were born from the 2000s onwards have more decentralized hierarchies building local networks but with a global connectivity. Indeed, such network structure resembles SLOC systems. Moreover, following the main features of SLOC systems, they have identified a common goal which is advancing the UN SDGs agenda.

The SLOC structure of TYNs is of particular relevance to this article because it represents the most recent TYNs' topology. Figure 1 shows a schematic representation of a SLOC network composed of individuals interconnected among themselves in a local network. The connections between individuals of a local network are generally made in-person and through online social media, which implies that they are quite fluid and dynamic. Some of the individuals within local networks are also connected globally. Because the strong local connections in SLOC systems, almost all members have as a secondary connection a foreign member. Most of the time, the connection among individuals of different local networks is established through online social media. Thus, the SLOC structure of TYNs required the growth of online social media platforms which took place during the 2000s (same period of time as the first SLOC TYNs). Figure 1 also exemplifies that the connection among individuals of different local networks brings along key educational and diplomatic aspects which are discussed in detail in the subsequent paragraphs.

An important aspect of TYNs is their great ability to act as an experiential educational platform owing to the global connections of its members. The reason for this is that they offer a rich ground to build crosscultural and cross-disciplinary bonding among individuals with considerably diverse backgrounds. Hence, development of interpersonal skills and empathy is a common feature of TYNs. Secondly, many of the TYNs also promote the development of projects that can lead to leadership and managerial skills. Emotional intelligence (and concomitantly empathy) as well as leadership skills are among the key cross-functional skills required for the future jobs (The Future of Jobs Report 2018) and, hence, experiential education on these areas are quite important for the TYNs members development. Moreover, as these networks advance educational skills globally they may indirectly impact SDGs 1-3 (Dawes, 2020). In addition, as they focus on promoting projects aligned with all UN SDGs, it implies that they can have a vast impact on the agenda.

All TYNs analyzed in this article have been created with common goals to tackle mutual challenges and advance the UN SDGs agenda. An exception to this is Shaping Horizons which, in addition to having such goals, from its inception it was created to advocate for multilateral PD activities between the UK and Latin America. According to non-traditional views of PD (Ayhan, 2019), both intended and unintended activities 
that influence the international agenda can be considered within the scope of PD. This is in agreement with the consensus that transnational networks can influence PD and, in fact, maximize the influence of the individuals on them (Haas, 1992; Keck and Sikkink, 2014). In addition, If the individuals involved in such transnational networks are key stakeholders influencing the political agendas of their respective countries, then the influence of such networks on PD activities can be maximized (Ayhan, 2019). Hence, the fact that TYNs are made of influential individuals from a network consisting of a broad range of disciplines implies that their influence to PD can be of considerable magnitude.

An important aspect of TYNs is the age of their members which implies that, in most cases, despite being influential individuals they have not yet achieved their professional and/or personal maturity. This implies a dynamic and constantly evolving impact of TYNs on PD activities. This is because the interaction and exchange of ideas of these individuals can influence their own personality, making them more prone to accept and understand diverse backgrounds. This has been highlighted to have a positive impact on PD activities (Payne, 2009). TYNs also promote long-term interpersonal relationships which are known to influence diplomatic relations (Carosso et al., 2019a; Cull, 2019). The relationship between education and PD activities through TYNs discussed here are based on global connections. We argue that there is an important aspect of recent TYNs with a SLOC topology that is worth highlighting. Because of the fluid and dynamic connection of individuals within local networks, we speculate based on experience, that the influence of the local individuals which have global connections may be extrapolated to the local individuals which have not yet had a connection with foreign TYNs' individuals themselves. Owing to this dynamic influence of TYNs on PD activities, the long-term influence of TYNs on PD can be enormous and warrants future research (Zhang and Swartz, 2009; Carmel and Richman, 2013).

To conclude, we provided a critical analysis of exemplary transnational youth networks and discussed their rich experiential educational opportunities in terms of developing their members' cross-disciplinary, crosscultural, and leadership skills. We also stress that transnational youth networks may become key influencers of public diplomacy activities because they serve as a means to coordinate and align the ideas and values of their members. In addition, they also help establish interpersonal relationships among their members which can also influence public diplomacy. The fact that members of transnational youth networks are selected based on their societal influence and young age is a unique aspect that may further increase the influence of these networks on public diplomacy activities over time. We argue that research on the educational and public diplomacy components of transnational youth networks is quite important as it can help understand and potentially amplify their impact on advancing the United Nations Sustainable Development Goals agenda.

\section{Conflict of Interest Statement}

The authors declare that the research was conducted in the absence of any commercial or financial relationships that could be construed as a potential conflict of interest.

\section{Author Contributions}

M.A. wrote the manuscript and coordinated the work. ZS.SZ. and M.A.M.-R. contributed to the content. 


\section{Acknowledgments}

M.A. acknowledges the support of the Global Challenges Research Fund grant number 102642, project code: AIAG/005. M.A.M.-R. is supported by the NIH UCSF-CTSI 5TL1TR001871-04 grant.

\section{References}

Ayhan, K. J. (2019). The Boundaries of Public Diplomacy and Nonstate Actors: A Taxonomy of Perspectives. International Studies Perspectives 20, 63-83.

Carmel, E., and Richman, J. (2013). Building International Social Capital at the Startup Chile Accelerator. Rochester, NY: Social Science Research Network.

Carosso, G. A., Ferreira, L. M. R., and Mostajo-Radji, M. A. (2019a). Developing Brains, Developing Nations: Can Scientists Be Effective Non-state Diplomats? Front. Educ. 4.

Carosso, G. A., Ferreira, L. M. R., and Mostajo-Radji, M. A. (2019b). Scientists as non-state actors of public diplomacy. Nature Human Behaviour 3, 1129-1130.

Castells, M. (2008). The new public sphere: Global civil society, communication networks, and global governance. The aNNalS of the american academy of Political and Social Science 616, 78-93.

Cull, N. J. (2019). Public diplomacy: foundations for global engagement in the digital age. John Wiley \& Sons.

Dawes, J. H. P. (2020). Are the Sustainable Development Goals self-consistent and mutually achievable? Sustainable Development 28, 101-117.

Gad, K. (2009). Teen Guide to Global Action. Green Teacher, 44.

Gilboa, E. (2008). Searching for a theory of public diplomacy. The annals of the American academy of political and social science 616, 55-77.

Gregory, B. (2008). Public diplomacy: Sunrise of an academic field. The Annals of the American Academy of Political and Social Science 616, 274-290.

Haas, P. M. (1992). Introduction: epistemic communities and international policy coordination. International organization 46, 1-35.

Joplin, L. (1981). On Defining Experiential Education. Journal of Experiential Education 4, 17-20.

Keck, M. E., and Sikkink, K. (2014). Activists beyond borders: Advocacy networks in international politics. Cornell University Press.

Manzini, E. (2010). Small, local, open and connected. Sustainability in Design: Now!, 14.

Nye Jr, J. S. (2008). Public diplomacy and soft power. The annals of the American academy of political and social science 616, 94-109. 
Payne, J. G. (2009). Trends in Global Public Relations and Grassroots Diplomacy. American Behavioral Scientist 53, 487-492.

Sekara, V., Stopczynski, A., and Lehmann, S. (2016). Fundamental structures of dynamic social networks. Proc Natl Acad Sci USA 113, 9977-9982.

Sustainable Development Goals Available at: https://sustainabledevelopment.un.org/?menu=1300 [Accessed May 2, 2018].

The Future of Jobs Report 2018 World Economic Forum. Available at:

https://www.weforum.org/reports/the-future-of-jobs-report-2018/ [Accessed March 2, 2020].

United Nations Population Division Available at:

https://www.un.org/en/development/desa/population/index.asp [Accessed March 2, 2020].

United Nations Social Development Network Available at: https://unsdn.org/ [Accessed March 2, 2020].

Youth 2030: The UN Youth Strategy Office of the Secretary-General's Envoy on Youth. Available at: https://www.un.org/youthenvoy/youth-un/ [Accessed March 2, 2020].

Zhang, J., and Swartz, B. C. (2009). Public diplomacy to promote Global Public Goods (GPG):

Conceptual expansion, ethical grounds, and rhetoric. Public Relations Review 35, 382-387.
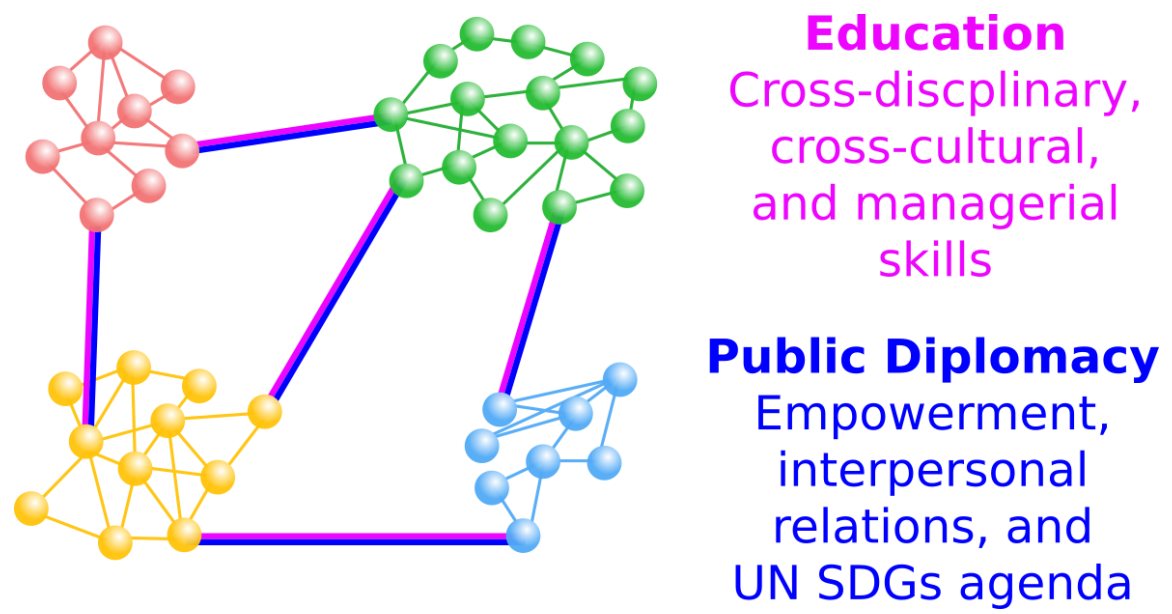

Figure 1. Transnational youth networks (TYNs) developed after the 2000s with a small, local, open and connected systems (SLOC) schematic topology. The relationships between individuals (circles) comprising local networks are shown with straight lines of the same color code as the individuals. The relationships among individuals from different local networks (i.e., global connections) are shown with two-color code lines to represent the importance of such connections on the educational and public diplomacy notions discussed. 


\begin{tabular}{|c|c|c|c|c|c|c|}
\hline Name & Website & $\begin{array}{l}\text { Year } \\
\text { funded }\end{array}$ & Goal & $\begin{array}{l}\text { Governanc } \\
\text { e }\end{array}$ & Main features & $\begin{array}{l}\text { Age } \\
\text { targe } \\
\text { t }\end{array}$ \\
\hline Rotaract & $\begin{array}{l}\text { https://www. } \\
\text { rotary.org/en } \\
\text { /get- } \\
\underline{\text { involved/rota }} \\
\underline{\text { act-clubs }}\end{array}$ & 1968 & $\begin{array}{l}\text { Leadership, } \\
\text { professional } \\
\text { and } \\
\text { community } \\
\text { service } \\
\text { organization }\end{array}$ & $\begin{array}{l}\text { Central } \\
\text { headquarter } \\
\mathrm{s}\end{array}$ & $\begin{array}{l}\text { Formal meetings, social } \\
\text { activities/events, service } \\
\text { projects work, and } \\
\text { professional/leadership } \\
\text { development workshops }\end{array}$ & $\begin{array}{l}18- \\
30\end{array}$ \\
\hline $\begin{array}{l}\text { Restless } \\
\text { develop } \\
\text { ment }\end{array}$ & $\frac{\underline{\text { https://restles }}}{\underline{\text { sdevelopmen }}}$ & 1985 & $\begin{array}{l}\text { Placing } \\
\text { young people } \\
\text { at the } \\
\text { forefront of } \\
\text { change } \\
\text { aligned with } \\
\text { the United } \\
\text { Nations } \\
\text { Sustainable } \\
\text { Development } \\
\text { Goals and } \\
\text { with } \\
\text { development } \\
\text { in India, } \\
\text { Nepal, Sierra } \\
\text { Leone, South } \\
\text { Africa, } \\
\text { Tanzania, } \\
\text { Uganda, } \\
\text { Zambia, and } \\
\text { Zimbabwe }\end{array}$ & $\begin{array}{l}\text { Central } \\
\text { headquarter } \\
\text { s initially. } \\
\text { Currently, } \\
\text { self- } \\
\text { governed } \\
\text { hubs in } \\
\text { different } \\
\text { countries }\end{array}$ & Country programs & $\begin{array}{l}18- \\
28\end{array}$ \\
\hline We & $\begin{array}{l}\frac{\text { https://www. }}{\text { we.org/en- }} \\
\underline{\text { CA/ }}\end{array}$ & 1995 & $\begin{array}{l}\text { Removing } \\
\text { barriers for } \\
\text { children's } \\
\text { education } \\
\text { and empower } \\
\text { their projects }\end{array}$ & $\begin{array}{l}\text { Central } \\
\text { Headquarter } \\
\mathrm{s} \text { and Board } \\
\text { of Directors }\end{array}$ & $\begin{array}{l}\text { Implements development } \\
\text { programmes related to } \\
\text { education, water, health, } \\
\text { food and economic } \\
\text { opportunities. Series of } \\
\text { conferences. }\end{array}$ & $0-18$ \\
\hline $\begin{array}{l}\text { Takingit } \\
\text { global }\end{array}$ & $\frac{\text { https://www. }}{\text { tigweb.org/ }}$ & 1999 & $\begin{array}{l}\text { Promoting } \\
\text { awareness } \\
\text { and } \\
\text { engagement }\end{array}$ & $\begin{array}{l}\text { Central } \\
\text { Headquarter } \\
\mathrm{s}\end{array}$ & $\begin{array}{l}\text { Online Social media } \\
\text { network for youth to raise } \\
\text { awareness, promote } \\
\text { discussion and encourage }\end{array}$ & $0-18$ \\
\hline
\end{tabular}




\begin{tabular}{|c|c|c|c|c|c|c|}
\hline & & & $\begin{array}{l}\text { among global } \\
\text { youth }\end{array}$ & & $\begin{array}{l}\text { action related to challenges } \\
\text { that affect local and global } \\
\text { communities. }\end{array}$ & \\
\hline $\begin{array}{l}\text { One } \\
\text { Young } \\
\text { World }\end{array}$ & $\begin{array}{l}\underline{\text { https://www. }} \\
\underline{\text { oneyoungwo }} \\
\underline{\text { rd.com/ }}\end{array}$ & 2009 & $\begin{array}{l}\text { Identifying, } \\
\text { promoting } \\
\text { and } \\
\text { connecting } \\
\text { the world's } \\
\text { young } \\
\text { leaders to } \\
\text { create more } \\
\text { responsible } \\
\text { and effective } \\
\text { leadership }\end{array}$ & $\begin{array}{l}\text { Central } \\
\text { headquarter } \\
\mathrm{s}\end{array}$ & $\begin{array}{l}\text { Annual summit, small } \\
\text { gatherings and support to } \\
\text { apply for funding and other } \\
\text { activities }\end{array}$ & $\begin{array}{l}18- \\
30\end{array}$ \\
\hline $\begin{array}{l}\text { Global } \\
\text { Young } \\
\text { Academ } \\
\text { y }\end{array}$ & $\begin{array}{l}\text { https://global } \\
\text { youngacade } \\
\text { my.net/ }\end{array}$ & 2010 & $\begin{array}{l}\text { Promoting } \\
\text { scientific } \\
\text { collaboration } \\
\text { s, outreach } \\
\text { and policy } \\
\text { across the } \\
\text { globe. }\end{array}$ & $\begin{array}{l}\text { Central } \\
\text { headquarter } \\
\mathrm{s} \quad \text { and } \\
\text { executive } \\
\text { board }\end{array}$ & $\begin{array}{l}\text { Annual summit, } \\
\text { establishment of national } \\
\text { young academies, science } \\
\text { and policy papers, and } \\
\text { outreach activities }\end{array}$ & $\begin{array}{l}30- \\
40\end{array}$ \\
\hline $\begin{array}{l}\text { Global } \\
\text { Shapers }\end{array}$ & $\begin{array}{l}\text { https://www. } \\
\text { globalshaper } \\
\underline{\text { s.org/ }}\end{array}$ & 2011 & $\begin{array}{l}\text { Network of } \\
\text { young people } \\
\text { driving } \\
\text { dialogue, } \\
\text { action and } \\
\text { change } \\
\text { aligned with } \\
\text { the United } \\
\text { Nations } \\
\text { Sustainable } \\
\text { Development } \\
\text { Goals }\end{array}$ & $\begin{array}{l}\text { Central } \\
\text { headquarter } \\
\mathrm{s} \text { and self- } \\
\text { governed } \\
\text { hubs in } \\
\text { cities }\end{array}$ & $\begin{array}{l}\text { Annual summit, regional } \\
\text { gatherings, participation at } \\
\text { events of the World } \\
\text { Economic Forum, funding } \\
\text { and other activities }\end{array}$ & $\begin{array}{l}18- \\
30\end{array}$ \\
\hline Sandbox & $\underline{\underline{\text { http://sandbo }}}$ & 2014 & $\begin{array}{l}\text { Network of } \\
\text { young people } \\
\text { leveraging } \\
\text { local power } \\
\text { for positive } \\
\text { change }\end{array}$ & $\begin{array}{l}\text { Central } \\
\text { headquarter } \\
\mathrm{s} \text { and self- } \\
\text { governed } \\
\text { hubs in } \\
\text { cities }\end{array}$ & $\begin{array}{l}\text { Annual summit and } \\
\text { regional gatherings }\end{array}$ & $\begin{array}{l}18- \\
30\end{array}$ \\
\hline $\begin{array}{l}\text { Internati } \\
\text { onal } \\
\text { Youth } \\
\text { Society }\end{array}$ & $\begin{array}{l}\underline{\text { https://intern }} \\
\text { ationalyouths } \\
\underline{\text { ociety.org/ }}\end{array}$ & 2017 & $\begin{array}{l}\text { Empowering } \\
\text { students and } \\
\text { young } \\
\text { professionals } \\
\text { to create } \\
\text { 'positive }\end{array}$ & $\begin{array}{l}\text { Central } \\
\text { Headquarter } \\
\text { s, Regional, } \\
\text { Zonal and } \\
\text { Country } \\
\text { Directors }\end{array}$ & $\begin{array}{l}\text { Youth conferences, camps, } \\
\text { campaigns, competitions, } \\
\text { exhibitions, festivals, } \\
\text { internships, workshops, } \\
\text { and awards. }\end{array}$ & $\begin{array}{l}10- \\
40\end{array}$ \\
\hline
\end{tabular}




\begin{tabular}{|c|c|c|c|c|c|c|}
\hline & & & $\begin{array}{l}\text { change' in } \\
\text { their local } \\
\text { communities } \\
\text { and around } \\
\text { the world }\end{array}$ & & & \\
\hline Unleash & $\underline{\underline{\text { https://unleas }}}$ & 2017 & $\begin{array}{l}\text { Global } \\
\text { innovation } \\
\text { lab to } \\
\text { develop } \\
\text { solutions to } \\
\text { meet the } \\
\text { United } \\
\text { Nations } \\
\text { Sustainable } \\
\text { Development } \\
\text { Goals }\end{array}$ & $\begin{array}{l}\text { Central } \\
\text { headquarter } \\
\mathrm{s} \text { and self- } \\
\text { governed } \\
\text { teams across } \\
\text { countries }\end{array}$ & 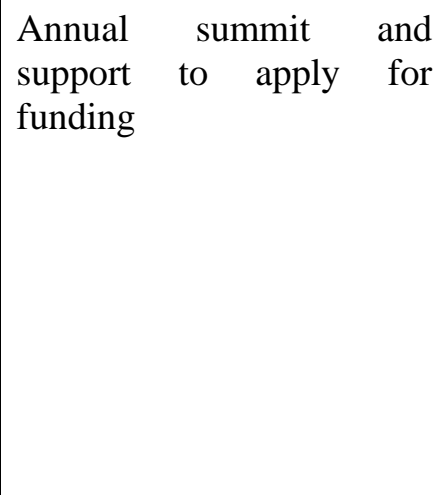 & $\begin{array}{l}18- \\
35\end{array}$ \\
\hline $\begin{array}{l}\text { Shaping } \\
\text { Horizons }\end{array}$ & $\begin{array}{l}\text { https://www. } \\
\text { shapinghoriz } \\
\text { ons.org/ }\end{array}$ & 2019 & $\begin{array}{l}\text { Network of } \\
\text { young } \\
\text { leaders } \\
\text { across Latin } \\
\text { America and } \\
\text { the UK } \\
\text { driving } \\
\text { change } \\
\text { aligned with } \\
\text { the United } \\
\text { Nations } \\
\text { Sustainable } \\
\text { Development } \\
\text { Goals }\end{array}$ & $\begin{array}{l}\text { Decentraliz } \\
\text { ed } \\
\text { headquarter } \\
\text { s and self- } \\
\text { governed } \\
\text { teams across } \\
\text { countries }\end{array}$ & $\begin{array}{l}\text { Biannual summit, regional } \\
\text { gatherings, funding, } \\
\text { professional/leadership } \\
\text { development workshops, } \\
\text { and other activities }\end{array}$ & $\begin{array}{l}18- \\
32\end{array}$ \\
\hline
\end{tabular}

Table 1: Summary of TYNs and their main features. The TYNs are ordered based on their year of creation and all webpages were accessed March 2, 2020. 